\title{
A STUDY ON FACTORS AFFECTING DIGITALIZATION OF IPO APPLICATION PROCESS
}

\author{
Darshini Dave \\ Dr. Nilam Panchal
}

\begin{abstract}
:
Initial Public Offering (IPO) is a type of public offering in which shares of an organization are offered to institutional and retail investors. An IPO is underwritten at least one investment bank, who additionally organize the shares to be listed on stock exchanges. Investors get to know about the IPO Opening through Internet/Digital Media, Broker, Television, Print Media, Friends, and Relatives. The preference of the same is being studied here through mean ranking. IPO application was traditionally done in offline mode. It can be now done online too. The factors affecting Online and offline application are ranked in this study. The factors like immediate blocking of amount, easiness to submit option, Easy Monitoring, time saving and less complexity are in favor of online Process. The Factors like Difficulty in monitoring progress, long time for blocking amount, Fear of application form getting lost, Long Queue for submission of Form and Problem in unblocking the amount are problematic in traditional (offline) method. These factors are ranked.
\end{abstract}

Keywords: IPO, Digitalization, Amount Blocking, Stock Exchanges

\section{INTRODUCTION}

An Initial Public Offer (IPO) alludes to the way toward offering portions of a private enterprise to the general population in another stock issuance. Open offer issuance permits an organization to raise capital from open speculators. The change from a private to an open organization can be a significant time for private financial specialists to completely acknowledge gains from their speculation as it regularly incorporates share premiums for current private speculators. In the meantime, it additionally permits open financial specialists to take an interest in the contribution.

An organization arranging an IPO will regularly choose a financier or guarantors. They will likewise pick a trade wherein the offers will be given and hence exchanged portions of the Dutch East India Company to the overall population. From that point forward, IPOs have been utilized as a path for organizations to raise capital from open openly. The term initial public offer (IPO) 
has been a trendy expression on Wall Street and among financial specialists for a considerable length of time.

The Dutch are credited with leading the primary present day IPO by offering speculators through the issuance of open offer possession. As the years progressed, IPOs have been known for upswing and downtrends in issuance. Singular segments additionally experience upswing and downtrends in issuance because of advancement and different other monetary variables. Tech IPOs duplicated at the stature of the website blast as new companies without incomes hurried to show themselves on the securities exchange.

The 2008 money related emergency brought about a year with minimal number of IPOs. After the downturn following the 2008 money related emergency, IPOs came to a standstill, and for certain years after, new postings were uncommon. All the more as of late, a great part of the IPO buzz has moved to an emphasis on supposed unicorns - new businesses that have arrived at private valuations of more than $\$ 1$ billion. Financial specialists and the media intensely conjecture on these organizations and their choice to open up to the world by means of an IPO or remain private.

IPO application system for investors For investment in any IPO investors need an demat account in registered depository participant for share delivery from company investor have an active demat account with Depository Participant (DP) So, step for the investors to invest in IPO by physical from are follow

Step-1 Open a demat account with a registered DP(Depository Participant).company which realise an IPO advertise for the to attract investors, before investing in any firm they have to check past records and statement. Future goals and objectives of the company has to be taken into consideration.

Step -2 After collecting all the information about the company if investor wants to participate in IPO they have to collect physical form from their broker and submit the same to them or in bank with the said amount cheque. they need to aware of application supported by blocking amount facility . When a company introduce IPO there will be minimum subscription amount as well as for HNIs and retails. There is bid price too, upper limit is called as cap price and lower limit is known as floor price

Step-3 Once the issue is closed, the company will allocate shares to investors, they will direct delivered shares in your demat account, they can check the allotment online on registered and transfer Agent of the company which is employed, if the issue is over subscribe you may not allot shares on that situation company will return your money after allotment day.

Step-4 After allotment shares are listing in stock market, investor can sell their allotted share by their trading account. They will get the selling amount after trading plus three days in their bank account by NEFT or cheque depend on depository participant. Good thing is that the money investor applied for IPO will be remains in their bank account blocked the interest on that will be given to them by bank.

\section{LITERATURE REVIEW}


Shunlin Song et. al. Inspect the IPO undervaluing and over valuation of the 948 Chinese IPO recorded during September 2006 to December 2011. They utilized CAR and BHAR model with the end goal of information examination for the present moment and long haul execution of IPO. They additionally viewed as various factors that can influence the exhibition of IPO. They locate that normal introductory return during the examination time frame is $66 \%$ where as under evaluating for short run and over valuation is $14.22 \% 44.53 \%$ separately. They inferred that these firm have incredibly high beginning profit for the main exchanging day are exaggerated and that under evaluating and over valuation have various determinants. .

Ritter Jay R. (1991) broke down 1526 IPOs from U.S. Market made during 1975 to 1984 . They note $16.4 \%$ normal beginning profit of IPOs for the principal exchanging day he likewise express that after a significant stretch IPOs are failed to meet expectations. He fined $61.86 \%$ normal absolute return over the many year holding period on coordinating of industry and market esteem. He likewise gives chance wrong measurement, misfortune, prevailing fashion and over idealism as a potential purpose behind underperformance. He discovered $29.13 \%$ total normal balanced return toward the finish of the three year which demonstrates the underperformance of IPO in since quite a while ago run. He additionally expresses that out of three year multi month returns are negative.

Ibbonton Roger G. et. Al. (1994) have dissected the IPOs recorded during 1960 to 1992 from the US showcase they found that normal beginning return from many years of 1960, 1970, 1980 and 1990 are $21.3 \%, 9.0 \%, 15.2 \%$ and $10.9 \%$ individually. They additionally examine 2439 IPOs during the 1975-1984 and found that offering cost underneath the $3 \$$ has return $42.8 \%$ and the IPOs with cost of more than $3 \$$ has $8.6 \%$ normal introductory returns. They likewise break down for since quite a while ago run execution of the IPOs. They discovered underperformance over a time of three years of first exchanging was $34.5 \%$ where as market return for comparative period was $61.9 \%$ in nut cell they called attention to that the evaluating for youthful IPO organizations as to open contribution is extremely troublesome. There are three difficulties for effective market for example short run undervaluing, degree of undervaluing and since a long time ago run underperformance.

Heerden Gillian Van and Alagidede Paul (2012) have inspected short run execution of IPO for first exchanging day to multi day of exchanging for that reason they examine 138 south African IPOs recorded on Johannesburg stock trade during the time of 2006 to 2010 . They note $108.33 \%$ beginning profit for the primary exchanging day. The market balanced abundance returns for the tenth day and twentieth day of exchanging is $195.89 \% 197.82 \%$ separately. Their exact discovering shows that the size fundamentally influences the presentation of IPO during the investigation time frame. Normal MAER of $9.521 \%$ for IPO recorded in excess of 500 pennies and $161.74 \%$ for IPO recorded under 500 pennies.

Forester Stephen R and Karolyi G. Andrew (1998) examine the since quite a while ago run execution of 333 of non US firm that raise capital in US showcases between the years 1982 to 1996. They analyze returns both preceding and resulting to posting. In general normal market return announced $46.8 \%$ in the a year before posting. Resulting to the posting CAR are accessible $9 \%$ throughout the following multi year. They likewise look at the exhibition of trade recorded 
ADRs with rules 1449 private situation. In this investigation they find that albeit private arrangement is more modern than other speculator yet ADR perform more than private situation

Mahammad Khalid Sohail and Mohamed Nasir (2007) researched 50 basic stock IPOs recorded on Karachi Stock Exchange for the period from the year 2000 to 2006. They assess the IPOs for short run and since quite a while ago run execution. They discover normal introductory profits $35.66 \%$ for the principal exchanging day and accommodate the undervaluing wonder with the other nations they likewise express that since quite a while ago run the Pakistani IPOs were failed to meet expectations their exact outcomes show normal BHARs is $-65.73 \%$ they additionally decide the determinants of undervaluing their outcomes show positive connection between ex-risk vulnerability and undervaluing such outcomes likewise concur with Ritters (1986) of uneven data hypothesis.

Dwindle Suren (2015) examines absolute 30 IPOs from Srilankan financial exchange during 1996 to 2000 out of 30 IPOs. 18 IPOs were privatized and staying 12 were non privatized contributions. They note $57.2 \%$ normal starting return of IPOs their outcome backing to the discoveries of created and developing economy the arrival is more with contrast with center salary nations like Malaysia (62\%), Mexico (36\%), Thailand (46.7\%) and Poland (44.4\%), the outcome for half year and year of exchanging as indicated by aggregate normal return is $14 \%$ and $11 \%$ separately. They additionally express that over a significant stretch of 3 years the IPO were failed to meet expectations and the arrival over time of years is - $12.96 \%$ they discover extent sway between starting return and market unpredictability, privatization, ex-risk vulnerability, and stock cost.

Lorne N. Switzer and Jean Francois bourdon (2011) examined 2310 IPOs during the period 1997 - 2006 from Canadian market. They note that administration quality is fundamental for solid monetary state of the business they find that age of the firm, instructive and proficient characteristics of supervisor, experience of administrators and so on. Arte decidedly related with the working execution of the business. They likewise recommend that CEO predominance and MBAs have decreased the exhibition of the organizations

Nitish Ranjan and Madhusoodan (2004) additionally thought about the size as a one of the significant determinant of value execution. Over the long haul IPOs from cowhide, paper, food, fired, building industry were failed to meet expectations without question while IPOs from banks and NBF foundations over performed.

M. Sadiqul Islam et. al (2011) explored 163 IPOs gave during 1992 to 2006 in Bangladesh. They break down short run and since a long time ago run execution of IPOs the investigation made for 2 months to 5 years from the posting date. They archived normal beginning profit for first exchanging day of $103.97 \%$ over an issue value, industry shrewd value execution are very from industry to industry. The designing business shows most elevated starting returns of $333.76 \%$ among all the business. They noticed that higher starting return in little issue and lower beginning return in enormous issue which reliable with the discoveries of universal examinations.

\section{Data Analysis:}


Towards Excellence: An Indexed, Refereed \& Peer Reviewed Journal of Higher Education / Darshini Dave \& Dr. Nilam Panchal/ Page 677-685

Table: 1 Friedman Test for sources of information

\begin{tabular}{|l|l|l|}
\hline Source of Information & Mean Rank & Rank \\
\hline Internet/Digital Media & 3.95 & 2 \\
\hline Broker & 4.6 & 1 \\
\hline Television & 3.54 & 4 \\
\hline Friends and Relatives & 3.76 & 3 \\
\hline Print Media & 3.32 & 5 \\
\hline Self & 1.84 & 6 \\
\hline
\end{tabular}

Table: 2 Data for Garrett Ranking (problematic factors-traditional system)

\begin{tabular}{|l|l|l|l|l|l|l|}
\hline Factors & 1 & 2 & 3 & 4 & 5 & Total \\
\hline Long time for blocking amount & 16 & 15 & 21 & 21 & 3 & 76 \\
\hline Fear of application form getting lost & 11 & 19 & 20 & 18 & 8 & 76 \\
\hline Difficulty in monitoring progress & 24 & 14 & 15 & 17 & 6 & 76 \\
\hline Long Queue for submission of Form & 22 & 24 & 15 & 13 & 2 & 76 \\
\hline Problem in unblocking the amount & 3 & 4 & 5 & 7 & 57 & 76 \\
\hline Total & 76 & 76 & 76 & 76 & 76 & \\
\hline
\end{tabular}

Table: 3 Value Calculation (problematic factors-traditional system)

\begin{tabular}{|l|l|l|l|}
\hline $\begin{array}{l}\text { GARRETT } \\
\text { RANKING }\end{array}$ & $\begin{array}{l}\text { FORMULA } \\
100(\mathrm{~N}-0.5) / \mathrm{N}\end{array}$ & $\begin{array}{l}\text { Calculated } \\
\text { Value }\end{array}$ & $\begin{array}{l}\text { Table } \\
\text { Value* }\end{array}$ \\
\hline Rank-1 & $100(1-0.50) / 5$ & 10 & 75 \\
\hline Rank-2 & $100(2-0.50) / 5$ & 30 & 60 \\
\hline Rank-3 & $100(3-0.50) / 5$ & 50 & 50 \\
\hline Rank-4 & $100(4-0.50) / 5$ & 70 & 40 \\
\hline Rank-5 & $100(5-0.50) / 5$ & 90 & 25 \\
\hline $\begin{array}{l}\text { Table value* is derived from Garrett's ranking table which is } \\
\text { given at the end of this document }\end{array}$ \\
\hline
\end{tabular}

Table: 4 Garrett Ranking (problematic factors-traditional system)

\begin{tabular}{|l|l|l|l|l|l|l|l|l|}
\hline Rank & 1 & 2 & 3 & 4 & 5 & & & \\
\hline Table Value & 75 & 60 & 50 & 40 & 25 & Total & $\begin{array}{l}\text { Average } \\
*\end{array}$ & Rank \\
\hline
\end{tabular}


Towards Excellence: An Indexed, Refereed \& Peer Reviewed Journal of Higher Education /

Darshini Dave \& Dr. Nilam Panchal/ Page 677-685

\begin{tabular}{|l|l|l|l|l|l|l|l|l|}
\begin{tabular}{|l} 
Long time for blocking \\
amount
\end{tabular} & 1200 & 900 & 1050 & 840 & 75 & 4065 & 53.49 & 3 \\
\hline $\begin{array}{l}\text { Fear of application form } \\
\text { getting lost }\end{array}$ & 825 & 1140 & 1000 & 720 & 200 & 3885 & 51.12 & 4 \\
\hline $\begin{array}{l}\text { Difficulty in monitoring } \\
\text { progress }\end{array}$ & 1800 & 840 & 750 & 680 & 150 & 4220 & 55.53 & 2 \\
\hline $\begin{array}{l}\text { Long Queue for } \\
\text { submission of Form }\end{array}$ & 1650 & 1440 & 750 & 520 & 50 & 4410 & 58.03 & 1 \\
\hline $\begin{array}{l}\text { Problem in unblocking the } \\
\text { amount }\end{array}$ & 225 & 240 & 250 & 280 & 1425 & 2420 & 31.84 & 5 \\
\hline Average* Total/76, where $76=$ sample size \\
\hline
\end{tabular}

Table: 5 Result- Final Ranking (problematic factors-traditional system)

\begin{tabular}{|l|l|}
\hline Rank & Factor \\
\hline 1 & Long Queue for submission of Form \\
\hline 2 & Difficulty in monitoring progress \\
\hline 3 & Long time for blocking amount \\
\hline 4 & Fear of application form getting lost \\
\hline 5 & Problem in unblocking the amount \\
\hline
\end{tabular}

Table: 6 Data for Garrett Ranking (advantageous factors-digital system)

\begin{tabular}{|l|l|l|l|l|l|l|}
\hline Factors Rank & 1 & 2 & 3 & 4 & 5 & Total \\
\hline Time saving & 17 & 16 & 14 & 11 & 18 & 76 \\
\hline $\begin{array}{l}\text { Less complex system compared to } \\
\text { offline system }\end{array}$ & 13 & 14 & 11 & 22 & 16 & 76 \\
\hline Easy to submit & 20 & 21 & 16 & 10 & 9 & 76 \\
\hline Easy to monitor process of subscription & 17 & 20 & 14 & 11 & 14 & 76 \\
\hline $\begin{array}{l}\text { Immediate block } \\
\text { amount }\end{array}$ & 9 & 5 & 21 & 22 & 19 & 76 \\
\hline Total & 76 & 76 & 76 & 76 & 76 & \\
\hline
\end{tabular}

Table: 7 Value Calculation (advantageous factors-digital system)

\begin{tabular}{|l|l|l|l|}
\hline $\begin{array}{l}\text { GARRETT } \\
\text { RANKING }\end{array}$ & $\begin{array}{l}\text { FORMULA } \\
100(\mathrm{~N}-0.5) / \mathrm{N}\end{array}$ & $\begin{array}{l}\text { Calculated } \\
\text { Value }\end{array}$ & $\begin{array}{l}\text { Table } \\
\text { Value* }\end{array}$ \\
\hline Rank-1 & $100(1-0.50) / 5$ & 10 & 75 \\
\hline Rank-2 & $100(2-0.50) / 5$ & 30 & 60 \\
\hline
\end{tabular}


Towards Excellence: An Indexed, Refereed \& Peer Reviewed Journal of Higher Education /

Darshini Dave \& Dr. Nilam Panchal/ Page 677-685

\begin{tabular}{|l|l|l|l|} 
Rank-3 & $100(3-0.50) / 5$ & 50 & 50 \\
\hline Rank-4 & $100(4-0.50) / 5$ & 70 & 40 \\
\hline Rank-5 & $100(5-0.50) / 5$ & 90 & 25 \\
\hline $\begin{array}{l}\text { Table value* is derived from Garrett's ranking table which is } \\
\text { given at the end of this document }\end{array}$
\end{tabular}

Table: 8 Garrett Ranking (advantageous factors-digital system)

\begin{tabular}{|c|c|c|c|c|c|c|c|c|}
\hline Rank & 1 & 2 & 3 & 4 & 5 & & & \\
\hline Table Value & 75 & 60 & 50 & 40 & 25 & Total & $\begin{array}{l}\text { Average } \\
*\end{array}$ & Rank \\
\hline Time saving & 1275 & 960 & 700 & 440 & 450 & 3825 & 50.33 & 3 \\
\hline $\begin{array}{l}\text { Less complex system compared } \\
\text { to offline system }\end{array}$ & 975 & 840 & 550 & 880 & 400 & 3645 & 47.96 & 4 \\
\hline Easy to submit & 1500 & 1260 & 800 & 400 & 225 & 4185 & 55.07 & 1 \\
\hline Easy to monitor process & 1275 & 1200 & 700 & 440 & 350 & 3965 & 52.17 & 2 \\
\hline $\begin{array}{l}\text { Immediate block of subscription } \\
\text { amount }\end{array}$ & 675 & 300 & 1050 & 880 & 475 & 3380 & 44.47 & 5 \\
\hline
\end{tabular}

Table: 9 Final Rating (advantageous factors-digital system)

\begin{tabular}{|l|l|}
\hline Rank & Factor \\
\hline 1 & Easy to submit \\
\hline 2 & Easy to monitor process \\
\hline 3 & Time saving \\
\hline 4 & Less complex system compared to offline system \\
\hline 5 & Immediate block of subscription amount \\
\hline
\end{tabular}

\section{Observation and Discussion:}

As per Table-1, The Friedman Test analyzed data in such a way that they got ranked as per their Mean Values. According to which brokers are the most popular source of information for IPO Subscription.

The Table-2 and Table-3 prepared data of the problematic factors of traditional system for Garrett Ranking as per the frequency of answers. The Table values were also derived.

The Table-4 gave the final ranking by finding average table values. As per this, Standing in long Queue for submission of Form is the biggest problem faced by users in traditional System.

The final ranking of all problems faced in traditional system are shown in Table-5. 
Darshini Dave \& Dr. Nilam Panchal/ Page 677-685

In the same way, The Table- 6 and Table-7 prepared data of advantageous factors-digital system for Garrett Ranking as per the frequency of answers. The Table values were also derived.

The Table- 8 gave the final ranking by finding average table values. As per this, Easy submission of Form is the biggest advantage observed by users in digital System.

The final ranking of advantageous factors-digital system are shown in Table-9.

\section{Conclusion:}

The Online Process of IPO Submission is easier and Customers prefer this over offline process mostly because of its easiness to submit option. The other advantages are respectively Easy Monitoring, time saving, less complexity and immediate blocking of amount. The main problematic Factor in traditional (offline) method is Long Queue for submission of Form. The other Factors are respectively Fear of application form getting lost, Difficulty in monitoring progress, long time for blocking amount and Problem in unblocking the amount. 


\title{
References
}

1. Ritter, J. R. (1991), "The Long-Run Performance of Initial Public Offering”, Journal of Finance, Vol. 46(1), pp 3-27.

2. Dyer, J.H. and Singh, H. (1998), “The Relational View: Cooperative Strategy and Sources of Interorganizational Competitive Advantage," Academy of Management Review, 23(4), 660-79.

3. Singh, B. and Mittal, R.K. (2003), "Underpricing of IPOs: Indian Experience", ICFAI, Journal of Applied Finance, Vol. 9(2), pp 29-42.

4. Arwah Arjun Madan (2003), „Investments in IPOs in the Indian Capital

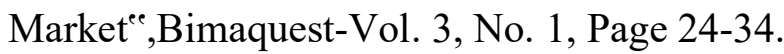

5. Avadhani, V.A. (2003), "Investment and Securities Market of India", Himalaya Publishing House Mumbai, Delhi Nagpur, Bangalore, Hyderabad.

6. Anand Adhikar (2010) "New Listings" Business Today, Vol.19, No.23, Page 94-95.

7. Mahesh Nayak (2010), ,Of Primary Concerns ${ }^{\text {ee }}$ Businessworld, Vol. 30, No. 25, 2-8, Page 30-36

8. Madhumita Gosh (2011) "IPOs: More Misses Than Hits", Dalal Street Investment Journal, Vol. 26. No. 9, Page 70.

9. Jagannadham Thunuguntla (2011) "IPOs: More Misses Than Hits", Dalal Street Investment Journal, Vol.26. No. 9, Page. 69.

10. Jignesh B. Shah and Smita Varodkar, November (2013) "Capital Market: Trends in India and abroad - impact of IPO Scam an Indian Capital Market", published in the Souvenir, All India Accounting Conference, November (2013)

\author{
Darshini Dave \\ Research Scholar \\ B.K. School of Professional and Management Studies \\ Gujarat University \\ Darshinidave12@gmail.com, M. 7405153189 \\ \& \\ Dr. Nilam Panchal \\ Associate Professor \& HOD Department of Public Policy and Governance \\ B.K. School of Professional and Management Studies \\ Gujarat University \\ nilamcpanchal@gmail.com, M. 9726676890
}

